\title{
Urgensi Informed Consent terhadap Perlindungan Hak-hak Pasien
}

\author{
The Urgency of Informed Consent for the Protection of \\ the Rights of Patients
}

\author{
Syafruddin $^{1}$ \& Ghansham Anand ${ }^{2}$ \\ ${ }^{1}$ Fakultas Hukum Universitas Borneo Tarakan \\ Jln. Amal Lama No. 1, Pantai Amal, Tarakan, Kalimantan Utara, Indonesia. \\ Tel./Fax:+62-811-5307023 E-mail: syaftrk2013@gmail.com \\ ${ }^{2}$ Fakultas Hukum Universitas Airlangga \\ Jln. Darmawangsa Dalam Selatan, Surabaya, Jawa Timur, Indonesia. \\ Tel./Fax: +62-31-5020454 E-mail: gansam_anand@ymail.com
}

Submitted: Jun 26, 2015; Reviewed: Jul 9, 2015; Accepted: Aug 14, 2015

\begin{abstract}
The right to health care for every citizen of Indonesia is a right guaranteed by the constitution, as set out in Article 28H Paragraph (1) of the 1945 Constitution which mandates the state to guarantee the rights of citizens to live in prosperity, among others, through the provision of better health care. The hospital is one of the institutions that provide health care facilities to every citizen through the efforts which allowed according to an adequate standard of health. One form of health care, is the provision of professional doctor and work according to the ethics of the medical profession. One form of professionalism of doctors within the framework of the protection of the rights of patients is the presence of informed consent as the rights of patients to obtain medical information from the hospital before getting certain medical actions that have an impact on the loss of life of patients. In connection with that, this article aims to explain philosophically dogmatic about the urgency of informed consent as a guarantee of protection of the rights of patients in hospitals. This paper, methodologically using normative analysis with a conceptual approach, so of course, legal materials that are used as a source of analysis, more concentrated on primary legal materials. In conclusion, the existence of informed consent plays an important role in terms of providing protection rights of patients to health services in hospitals, according mandate of the constitution, especially considering the fact mala practice of medicine that looks at some cases in hospitals in Indonesia, is the impact of neglect the application of informed consent that has not run as expected.
\end{abstract}

Keywords: Hospital; Informed Consent; The Rights of Patients 


\begin{abstract}
Abstrak: Hak untuk mendapat pelayanan kesehatan bagi setiap warga negara Indonesia merupakan hak yang dijamin konstitusi, sebagaimana tercantum dalam Pasal $28 \mathrm{H}$ ayat (1) UUD NRI 1945 yang mengamanatkan negara untuk menjamin hak warga negara hidup sejahtera yang antara lain melalui pemberian pelayanan kesehatan yang lebih baik. Rumah sakit merupakan salah satu lembaga yang memberikan fasilitas pelayanan kesehatan kepada setiap warga negara melalui upaya-upaya yang memungkinkan menurut standar kesehatan yang memadai. Salah satu bentuk pelayanan kesehatan, adalah penyediaan tenaga dokter yang profesional dan bekerja sesuai etika profesi kedokteran. Salah satu bentuk profesionalitas dokter dalam kerangka perlindungan hakhak pasien adalah keberadaan informed consent sebagai hak pasien untuk mendapatkan informasi medis dari pihak rumah sakit sebelum mendapatkan tindakan-tindakan medis tertentu yang berdampak pada hilangnya nyawa pasien. Sehubungan dengan itulah, tulisan ini bertujuan menjelaskan secara filosofis dogmatik tentang urgensi informed consent sebagai jaminan perlindungan hak-hak pasien di rumah sakit. Tulisan ini, secara metodologis menggunakan analisis normatif dengan pendekatan konseptual, sehingga tentu saja, bahan-bahan hukum yang digunakan sebagai sumber analisis, lebih terkonsentrasi pada bahan-bahan hukum primer. Kesimpulannya, keberadaan informed consent memegang peranan sangat penting dalam kerangka memberikan perlindungan hak-hak pasien untuk mendapatkan pelayanan kesehatan di rumah sakit, sesuai amanah konstitusi, apalagi mengingat fakta mala praktek kedokteran yang tampak pada beberapa kasus di rumah sakit di Indonesia, merupakan dampak dari pengabaian penerapan informed consent yang belum berjalan sesuai harapan.
\end{abstract}

Kata Kunci: Hak Pasien; Informed Consent; Rumah Sakit

\section{PENDAHULUAN}

Salah satu kebutuhan primer yang sangat dibutuhkan oleh manusia adalah pelayanan kesehatan. Sebab manusia tidak akan dapat beraktivitas secara maksimal bila ia mengalami gangguan kesehatan baik fisik maupun mental. Untuk itulah, pelayanan kesehatan merupakan salah satu hak dasar yang harus dipenuhi oleh setiap manusia. Artinya, pelayanan kesehatan juga sesungguhnya merupakan kebutuhan primer sama seperti kebutuhan primer lainnya untuk menjamin kelangsungan hidup bagi manusia.

Dalam konteks negara Indonesia, pelayanan kesehatan merupakan hak setiap warga negara yang dijamin oleh konstitusi. Pasal 28 H Ayat (1) UUD 1945 Amandemen ke-4 telah meneguhkan komitmen negara untuk memberikan jaminan pelayanan kesehatan bahwa Setiap orang berhak hidup se- jahtera lahir dan batin, bertempat tinggal dan mendapatkan lingkungan hidup yang baik dan sehat serta berhak memperoleh pelayanan kesehatan.

Bentuk pelayanan kesehatan kepada masyarakat, antara lain penyediaan fasilitas kesehatan di rumah sakit dengan segala kelengkapannya yang memadai. Tak dapat dipungkiri, rumah sakit hingga saat ini, merupakan lembaga penyedia sarana dan prasarana kesehatan. Masyarakat Indonesia, masih menaruh harapan dan kepercayaan kepada rumah sakit utuk mendapatkan pelayanan kesehatan yang lebih baik. Untuk itulah, keberadaan rumah sakit memiliki peran strategis sebagai satu-satunya lembaga kesehatan yang secara konkrit mengejawentah memberikan perlindungan hak-hak pasien. Mestinya, rumah sakit tidak sekedar menjalankan fungsi menangani pasien secara medis atau 
melakukan tindakan-tindakan terapeutik tetapi rumah sakit seyogyanya juga memperhatikan secara serius hak-hak pasien terutama dalam hal menentukan pilihan tindakan medis yang dikehendakinya. Hak pasien untuk menentukan pilihan tindakan medis, juga merupakan bentuk pelayanan kesehatan yang secara filosofis sangat berkaitan erat dengan hak dasar setiap warga negara.

Pada galibnya, hak pasien untuk menentukan pilihan tindakan medis yang dikehendakinya, akan tegak melalui penerapan norma yang disebut dengan informed consent. Informed consent adalah persetujuan pasien untuk dilakukan perawatan atau pengobatan oleh dokter di rumah sakit setelah pasien diberikan penjelasan yang cukup oleh dokter mengenai berbagai hal seperti diagnosis dan terapi. ${ }^{1}$ Sebagai landasan yuridis, informed consent diatur dalam Peraturan Menteri Kesehatan Nomor 290/MENKES/ PER/III/2008 tentang Persetujuan Tindakan Kedokteran, Pasal 2 bahwa semua tindakan kedokteran yang akan dilakukan terhadap pasien harus mendapatkan persetujuan. Persetujuan yang dimaksud diberikan secara tertulis maupun lisan setelah diberikan penjelasan yang diperlukan tentang perlunya tindakan kedokteran dilakukan.

Informed consent lahir sebagai akibat adanya hubungan terapeutik antara dokter dengan pasiennya. Masing-masing pihak mempunyai hak dan kewajiban yang harus dihormati. Hak untuk menerima yang dimiliki seseorang akan bersinggungan dengan kewajiban pihak lain untuk memberi, demikian pula sebaliknya. Interaksi antara

Adami Chazawi. (2007). Malpraktik Kedokteran. Malang: Bayu Media, hlm. 37 dokter dan pasien menimbulkan hubungan hukum dalam hubungan transaksi terapeutik yaitu timbulnya hak dan kewajiban pada masing-masing pihak.

Pada fakta pelayanan kesehatan beberapa rumah sakit di Indonesia, ditemukan sejumlah kasus malpraktik kedokteran yang sebenarnya bermula pada tidak diterapkannya informed consent secara baik. Dalam tataran empirik misalnya, kasus dokter Ayu, dokter Hendry, dan dokter Hendy di Rumah Sakit Prof Dr RD Kandou Manado melakukan operasi Cito Secsio Sesaria terhadap korban Siska Makatey, juga pada kasus dokter Bambang Suprapto, Sp.BM., Surg, tidak mempunyai izin berpraktik Rumah Sakit Dinas Kesehatan Tentara (DKT) Madiun, korbannya adalah pasien Johanes Tri Handoko.

Problematika informed consent yang tidak diterapkan secara baik sebagai bagian integral dalam kerangka pelayanan kesehatan rumah sakit di Indonesia, terutama juga sangat terkait dengan pengaturan dogmatik menyangkut informed consent, yang hanya merujuk pada pengaturan pada tingkat menteri yang tidak mengikat dan tidak ada sanksi hukum. ${ }^{2}$ Pengaturan perundang-undangan bidang kedokteran tidak jelas mengatur perselisihan dalam bidang kedokteran atau dengan kata lain tidak ada "hukum kedokteran" yang dapat dijadikan dasar hukum apabila terjadi pengabaian atas informed concent. Tidak adanya pengaturan dalam Undangundang Kedokteraan terkait informed concent, berakibat pada hak-hak pasien dalam menuntut hak atau atas transaksi terapeutik

2 Peraturan Menteri Kesehatan Republik Indonesia Nomor 290/Menkes/Per/III/2008 tentang Persetujuan Tindakan Kedokteran 
yang merugikan pasien. Hal ini diperparah dengan pemahaman aparat penegak hukum dalam hal tidak dilaksanakan informed concent dalam tindakan medis oleh dokter yang berakibat pada malpraktik kedokteran.

Sehubungan dengan itu, tujuan penulisan ini: Pertama, hendak mengungkap makna filosofis informed concent sebagai kerangka fundamental bagi perlindungan hak-hak pasien di rumah sakit. Kedua, mengurai urgensi informed concent terhadap perlindungan hak-hak pasien di rumah sakit. Dua tujuan penulisan yang digagas penulis, adalah beranjak pada isu utama permasalahan yang dihadapi oleh pasien rumah sakit di Indonesia hingga saat ini, yang kurang mengedepankan informed concent sebagai bagian tak terpisahkan dari upaya perlindungan hak-hak pasien di rumah sakit.

\section{METODE}

Karakter penulisan ini tetap konsisten dengan menggunakan tipe penelitian hukum normatif. Penelitian hukum normatif merupakan ciri khas dari tipe penelitian hukum yang menempatkan disiplin ilmu hukum sebagai salah satu bidang ilmu yang bersifat sui generis, sebab itu penelitian hukum normatif selalu merupakan proses penelitian untuk menemukan aturan hukum, prinsipprinsip hukum, maupun doktrin-doktrin hukum guna menjawab masalah pokok hukum yang dihadapi ${ }^{3}$.

Beranjak dari tipe penelitian ini yang sifatnya normatif, maka sumber bahan hukum yang digunakan sebagai rujukan analisis, mencakup sumber bahan hukum primer

Peter Mahmud Marzuki. (2005). Penelitian Hukum. Jakarta: Prenada Media Grup, hlm. 93. yakni Undang-Undang Kesehatan, Undang-Undang Praktik Kedokteran, Undangundang Perlindungan Konsumen, Kitab Undang-Undang Hukum Pidana, BW, dan peraturan pelaksanan yang terkait informed consent yang berimplikasi malpraktik kedokter serta putusan pengadilan yang sudah mempunyai kekuatan hukum tetap. Juga bahan hukum sekunder, berupa hasil karya dari kalangan ilmuwan hukum, misalnya, jurnal, majalah ilmiah hukum, media massa, internet dan pandangan atau doktrin yang terkait prinsip-prinsip informed consent yang berimplikasi malpraktik kedokter.

Semua bahan hukum tersebut, dikumpulkan dengan menggunakan metode bola salju, kemudian diolah dengan melakukan inventarisasi terhadap semua bahan hukum yang relevan dan langkah selanjutnya adalah melakukan analisis terhadap semua bahan hukum dimaksud secara sistematis kualitatif dengan merujuk prinsip-prinsip informed consent sebagai dasar berpijaknya.

\section{ANALISIS DAN PEMBAHASAN}

\section{Konsep Informed Consent}

Hingga saat ini konsep dogmatik Informed Consent belum terumus pada tataran undangundang. Secara dogmatik, konsep informed consent hanya terumus baku dalam Peraturan Menteri kesehatan Nomor 290/MENKES/ PER/III/2008 tentang Persetujuan Tindakan Kedokteran, yaitu Pasal 2 bahwa semua tindakan kedokteran yang akan dilakukan terhadap pasien harus mendapatkan persetujuan. Persetujuan yang dimaksud diberikan secara tertulis maupun lisan setelah diberikan penjelasan yang diperlukan tentang perlunya tindakan kedokteran dilakukan. 
Dari penguraian Pasal 2 peraturan menteri kesehatan, dapat diambil kesimpulan bahwa informed consent merupakan persetujuan kehendak dari pihak pasien yang bisa diwakilkan oleh pihak keluarga terdekat untuk mendapatkan tindakan medis tertentu setelah memperoleh penjelasan yang cukup dari pihak dokter atau rumah sakit mengenai perlunya tindakan dokter terhadap penyakit yang diderita pihak pasien. Dengan demikian, Informed consent lahir sebagai akibat ada hubungan terapeutik antara dokter dengan pasiennya. Masing-masing pihak mempunyai hak dan kewajiban yang harus dihormati. Hak untuk menerima yang dimiliki seseorang akan bersinggungan dengan kewajiban pihak lain untuk memberi. Demikian pula sebaliknya, Interaksi antara dokter dan pasien menimbulkan hubungan hukum dalam hubungan transaksi terapeutik yaitu timbulnya hak dan kewajiban pada masing-masing pihak.

Persoalan hak dan kewajiban dalam hubungan transaksi terapeutik, dalam perkembangan ilmu kedokteran, khususnya informed consent telah menjadi topik perdebatan dan diskusi kritis dikalangan ilmuwan dan praktisi dalam bidang kedokteran ${ }^{4}$ dan hukum. Pada profesi kedokteran ada hal

4 CIOM. (2002). International Ethical Guidelines for Biomedical Research Involving Human Subject, Geneva, hlm.12. Diuraikan bahwa Organisasi Kesehatan Dunia (WHO) bekerja sama dengan Council for International Organizations of Medical Sciences (CIOMS) menyusun buku International Ethical Guidelines for Biomedical Research Involving Human Prepared. Buku panduan menjelaskan tindakan medis atau penelitian yang melibatkan manusia sebagai obyeknya, perlu memperhatikan secara seksama dan mengimplementasikan standar etika dan nilai-nilai kultural terkait dengan otonomi individu dan informed consent. yang fundamental yang harus dipegang yakni etik kedokteran. Etik kedokteran dalam hal memberi pertolongan, berbuat baik dan tidak merugikan orang lain (pasien). Terkait dengan etik kedokteran terjadi perdebatan dengan informed consent, pada posisi mana pemahaman itu dalam hubungan ilmu kedokteran dan hukum. Untuk itu perlu dikaji dengan pendekatan interdisipliner ilmu, tujuannya agar informed consent dapat dipahami secara lebih komprehensif.

Pendekatan interdisiplin ilmu secara komprehensif, maka menempatkan informed consent sebagai sesuatu akibat dalam bidang kedokteran yang berimplikasi dipraktik kedokteran yang berakibat hukum. Implikasi dalam praktik kedokteran dalam hal ini, dimaknai, bahwa prosedur informed consent yang tidak dilakukan, menimbulkan dampak atau akibat terhadap beberapa kasus malpraktik kedokteran. Terkait dengan malpraktik dokter yang berhubungan dengan informed consent, hingga saat ini masih menimbulkan polemik antara bidang kedokteran dan bidang hukum. Menurut pakar kedokteran, informed consent secara prinsip tidak perlu diatur karena sudah merupakan bagian dari tugas dokter. Sedangkan para pakar hukum berpendapat bahwa hak-hak pasien harus dijelaskan, dilindungi dan bila perlu mesti ada pemberian sanksi hukum jika terdapat tindakan medis yang dilakukan secara tidak prosedur oleh dokter terhadap pasien.

Sejak dahulu informed consent memang sudah dibahas dalam bidang kajian kedokteran, namun gagasan konsep ini tidak serta merta diterima begitu saja oleh semua pihak, terutama dari kalangan ikatan dokter. Inilah yang menyebabkan munculnya perbe- 
daan pendapat, sehingga membentuk sebuah polaritas, yakni pihak yang setuju dengan informed consent di satu sisi dan mereka yang menolak pada sisi yang lain. Namun pada perkembangan selanjutnya, dimulailah suatu paradigma baru bidang kedokteran bahwa untuk perlindungan hak-hak pasien atas tindakan medis yang diterimanya terhadap tindakan dokter di rumah sakit, disepakati suatu konsep etika dan hukum yang tertuang dalam apa yang disebut informed consent. Artinya, informed consent inilah yang menjadi dasar kode etik sekaligus dasar kesepakatan hukum antara dokter dan pasien dalam meletakkan kerangka tanggung jawab dokter serta perlindungan hak-hak pasien.

Informed consent pada dasarnya adalah sebuah proses komunikasi yang berkesinambungan. ${ }^{5}$ Dalam konteks ini, informed consent merupakan pemindahan paradigma pengambilan keputusan, dari yang berpusat di tangan dokter ke tangan pasien. Informed consent juga mensyaratkan keterbukaan (disclosure), sehingga dokter harus mendapatkan informasi sejelas-jelasnya seperti misalnya dengan melacak sejarah keluarga atau semua yang terlibat dengan keberadaan pasien. Dengan begitu, melalui informed consent dokter akan menjadi semakin cermat dalam melakukan diagnosa terhadap diri pasien termasuk juga kehati-hatian

5 Selain sebuah komunikasi, informed consent terlihat abstrak dan ideologis. Dalam pemahaman etis, informed consent adalah upaya untuk memohon secara halus kepada pasien dan dengan otonomi yang dimiliki oleh pasien, dia menerima penjelasan bahwa tujuan tindakan medis kepada dirinya merupakan pilihan otonomnya dan bukan atas dorongan atau paksaan orang lain. Daniel E, et.al, 2012 "Informed consent for clinical treatment" in Canadian Medical Association, hlm.1. Avaialble online at: (http://www.cmaj.ca/content/184/5/533. full) Diunduh 4 September 2013. pihak dokter melakukan tindakan-tindakan medis tertentu secara profesional dengan tetap menjaga prisip-prinsip etika kedokteran.

Dalam melakukan tindakan medis pada pasien, sebagai bagian dari informed consent, maka dokter harus menjelaskan beberapa hal, yaitu:

a) Garis besar seluk beluk penyakit yang diderita dan prosedur perawatan/pengobatan yang akan diberikan/diterapkan;

b) Resiko yang dihadapi, misalnya komplikasi yang diduga akan timbul;

c) Prospek/prognosis keberhasilan ataupun kegagalan;

d) Alternatif metode perawatan/pengobatan;

e) Hal-hal yang dapat terjadi bila pasien menolak untuk memberikan persetujuan; dan

f) Prosedur perawatan/pengobatan yang akan dilakukan merupakan suatu percobaan atau menyimpang dari kebiasaan, bila hal itu yang akan dilakukan.

Dokter juga perlu menyampaikan (meskipun hanya sekilas), mengenai cara kerja dan pengalamannya dalam melakukan tindakan medis tersebut. Informasi/keterangan yang wajib diberikan sebelum suatu tindakan kedokteran dilaksanakan adalah ${ }^{6}$ :

a) Diagnosa yang telah ditegakkan;

b) Sifat dan luasnya tindakan yang akan dilakukan;

c) Manfaat dan urgensinya dilakukan tindakan tersebut;

6 Chirisdiono Achdiat. (2006). Dinamika Etika \& Hukum Kedokteran Dalam Tantangan Zaman. Jakarta: Buku Kedokteran EGC, hlm. 28. 
d) Resiko resiko dan komplikasi yang mungkin terjadi daripada tindakan kedokteran tersebut;

e) Konsekuensinya bila tidak dilakukan tindakan tersebut dan adakah alternatif cara pengobatan yang lain; dan

f) Kadangkala biaya yang menyangkut tindakan kedokteran tersebut.

Menyangkut resiko yang harus diinformasikan kepada pasien yang dimintakan persetujuan tindakan kedokteran yaitu 1). Resiko yang melekat pada tindakan kedokteran tersebut, dan 2). Resiko yang tidak bisa diperkirakan sebelumnya. Terkait indikasi kemungkinan perluasan tindakan kedokteran, dokter yang akan melakukan tindakan juga harus memberikan penjelasan (pasal 11 ayat (1) PerMenKes Nomor 290/Menkes/PER/ III/2008). Penjelasan kemungkinan perluasan tindakan kedokteran sebagaimana dimaksud dalam ayat 1 merupakan dasar dari persetujuan yang termaktub dalam ayat (2). Pengecualian terhadap keharusan pemberian informasi sebelum dimintakan persetujuan tindakan kedokteran adalah: 1) Dalam keadaan gawat darurat (emergency), dimana dokter harus segera bertindak untuk menyelamatkan jiwa; dan 2). Keadaan emosi pasien yang sangat labil sehingga ia tidak bisa menghadapi situasi dirinya.

Secara teoritis, bentuk-bentuk informed consent, dapat dikategorikan tiga bentuk, mencakup:

1. Persetujuan Tertulis, biasanya diperlukan untuk tindakan medis yang mengandung resiko besar, sebagaimana ditegaskan dalam PerMenKes Nomor 290/Menkes/Per/III/2008 Pasal 3 ayat (1) dan SK PB-IDI Nomor 319/
PB/A.4/88 butir 3, yaitu intinya setiap tindakan medis yang mengandung resiko cukup besar, mengharuskan adanya persetujuan tertulis, setelah sebelumnya pihak pasien memperoleh informasi yang adekuat tentang perlunya tindakan medis serta resiko yang berkaitan dengannya (telah terjadi informed consent);

2. Persetujuan Lisan, biasanya diperlukan untuk tindakan medis yang bersifat non-invasif dan tidak mengandung resiko tinggi, yang diberikan oleh pihak pasien; ${ }^{7}$

3. Persetujuan dengan isyarat, dilakukan pasien melalui isyarat, misalnya pasien yang akan disuntik atau diperiksa tekanan darahnya, langsung menyodorkan lengannya sebagai tanda menyetujui tindakan yang akan dilakukan terhadap dirinya ${ }^{8}$

Berdasarkan uraian tiga bentuk informed consent tersebut, maka informed consent selalu melibatkan unsur kesukarelaan pasien terhadap apa yang menjadi tindakan medis seorang dokter terhadap dirinya. Transaksi terapeutik persetujuan yang terjadi antara dokter dengan pasien bukan dibidang pengobatan saja tetapi lebih luas, mencakup bidang diagnostik, preventif, rehabilitatif maupun promotif. $^{9}$ Terkait dengan sikap

Burke, Sarah Elizabeth (2008). The Doctor-Patient Relationship: An Exploration of Trainee Doctors' Views. (Dissertation). School of Education The University of Birmingham, hlm. 109-110

8 B.M. Stanley, D.J. Walters and G.J. Maddern. (1998). "Informed Consent: How Much Information is Enough?" ANZ Journal of Surgery, hlm. 788-91.

9 M. Jusuf Hanafiah dan Amri Amir. (1999). Etika Kedokteran \& Hukum Kedokteran. Jakarta: Penerbit Buku Kedokteran EGC, hlm. 39 
saling percaya ini tumbuh apabila terjalin komunikasi secara terbuka dan jujur antara dokter dengan pasien. Untuk itu masingmasing pihak (baik dokter maupun pasien) dapat saling memberikan informasi yang diperlukan bagi terlaksanakan kerjasama yang baik dan tercapainya tujuan pelayanan kesehatan.

Pada konteks ini transaksi terapeutik yang ada merujuk pada ketentuan Pasal 1234 Burgelijk Wetboek (selanjutnya disebut BW) yang menyebutkan, bahwa tiap perikatan adalah untuk memberikan sesuatu, untuk berbuat sesuatu atau untuk tidak berbuat sesuatu. Hubungan yang terjadi dalam transaksi terapeutik inilah yang menjadi dasar dalam pelayanan kesehatan, dengan mengedepankan prinsip etik yang dianut dokter yaitu dalam rangka memberi pertolongan, berbuat baik dan tidak merugikan pasien. Prinsip etik dalam hal memberi pertolongan harus tuntas atau sampai sembuh.

Makna Filosofis Informed Concent sebagai Kerangka Fundamental Perlindungan Hak-hak Pasien

Pada paragraf sebelumnya, telah diurai tentang determinasi informed consent, yang pada hakikatnya merupakan hubungan komunikasi antara dokter dengan pasien di rumah sakit yang sangat terkait erat dengan pemberian informasi oleh dokter kepada pasien tentang tindakan medis yang akan diterimanya sebagai bagian upaya penyembuhan sakit yang diderita oleh pasien. Peletakan informed consent ini sekaligus hendak meletakkan hubungan terapeutik antara dokter dan pasien dalam kerangka hubungan ke- percayaan pasien kepada dokter juga sebaliknya penekanan keprofesian dokter dalam menjalankan tugas-tugas medis terhadap pasien itu sendiri.

Kerangka pembahasan ini, penulis tidak sekedar menggambarkan konsep informed consent pada bingkai bersifat dogmatik-normatif yang menjelaskan hubungan hukum antara dokter dan pasien dalam bentuk pelayanan medis, tetapi tataran uraian ini lebih menukik pada aspek kefilsafatan hakikat informed consent sebagai sebuah konsep yang secara mendasar adalah untuk memberikan perlindungan hak-hak pasien secara menyeluruh. Dari uraian penjelasan filosofis inilah, maka informed consent akan terlihat sebagai sebuah konsep fundamental yang inheren dengan perlindungan hak-hak pasien untuk mendapatkan pelayanan kesehatan lebih baik dan profesional di rumah sakit.

Sehubungan dengan perbincangan pelayanan kesehatan, tentu saja sangat terkait dengan hak-hak dasar manusia yang bersifat naluriah. Artinya, kesehatan merupakan salah satu kebutuhan primer bagi manusia karena itu sangat terkait erat dengan kelangsungan eksistensi kehidupan manusia di permukaan bumi ini. Memang benar dalam teori ekonomi, kebutuhan primer manusia mencakup tiga yaitu pangan, sandang, dan papan. Tetapi kesehatan juga merupakan kebutuhan primer manusia. Sebab tanpa kesehatan manusia tidak akan mungkin menjalankan berbagai aktivitasnya. Sehingga kesehatan akan selalu menjadi hak dasar manusia. Hak ini sebagai hak asasi manusia dalam arti yang luas, yaitu menyangkut Hak Asasi Sosial ${ }^{10}$.

10 Philipus. M. Hadjon, (2000). Perlindungan Hukum Bagi Rakyat Indonesia. Yogyakarta: Peradapan, hlm. 56. 
Menurut John Locke dalam bukunya Second Treaties of Government bahwa dalam diri manusia dapat ditemukan asas-asas yang merupakan hak-hak aslinya. ${ }^{11}$

Dari Pemahaman ini, maka sesungguhnya klasifikasi hak asasi itu, mencakup dua pembagian yakni hak asasi yang bersumber langsung dari aspek manusiawi dalam tatanan kehidupan semesta yang bersifat abadi dan universal, serta sangat terkait erat dengan harkat dan martabatnya. Sedangkan hak yang tidak asasi itu bersumber dari aspek kehidupan hubungan antar pribadi yang bisa berbeda dan dibatasi menurut tempat, waktu, dan kondisi tertentu.

Terkait dengan informed consent maka informed consent dapat dimaknai sebagai pengakuan terhadap asas kesamaan hak antara pasien dan dokter, selain itu informed consent akan menjadi daya pengikat bagi pemangku kebijakan (pemerintah) guna senantiasa konsen dalam rangka menyusun dan melaksanakan program-program untuk menciptakan derajat kesehatan yang lebih baik. Konsistensi negara, dalam ini pemerintah untuk menjabarkan pengakuan yang menimbulkan kewajiban guna mengupayakan perlindungan persamaan di bidang kesehatan.

Dengan demikian, secara filosofis informed consent akan mendudukkan faktor persetujuan pasien sebagai hak pasien terhadap tindakan medis yang dilakukan.

11 Purnadi Purbacaraka. (1982). "Hak Milik Keadilan dan kemakmuran Tinjauan Falsafah Hukum". Jakarta: Ghalia Indonesia, hlm. 8. Dalam buku ini dijelaskan bahwa hak kesehatan merupakan hak dasar dan tidak dapat diganggu gugat oleh siapapun termasuk negara sekalipun. Pendapat John Locke tersebut pada dasarnya sama dengan Bill of Rights di Inggris yang sangat berpengaruh besar di masyarakat beradab.
Persetujuan pasien ini yang pada hakikatnya merefleksikan kesepakatan antara kedua belah pihak yaitu antara dokter dengan pasien, pada akhirnya akan menimbulkan terjadinya hubungan hukum yang dapat menjamin kepentingan masing-masing pihak. Konteks kepentingan yang diterjemahkan dalam persetujuan yang terdapat dalam informed consent, tentunya berkenaan dengan tindakan medis. Berpijak dari pemikiran filosofis inilah, informed consent sesungguhnya memberikan makna yang lebih dalam bahwa mestinya kepentingan pasien atas kesehatannya harus dihargai dan dihormati oleh orang lain yakni dokter yang melakukan tindakan medis.

Informed consent tidaklah sekedar merupakan persetujuan kehendak dari pasien tetapi ia juga bentuk komitmen perlindungan hak-hak pasien dari segala tindakan medis yang kemungkinan berakibat fatal terhadap diri pasien sampai pada tahap yang dapat menghilangkan nyawa pasien. Sebab kedudukan pasien dalam hal tindakan medis tidaklah serta serta merta menjadi objek percobaan oleh dokter tetapi penanganan pasien mesti tetap dalam kerangka batas-batas etika profesionalitas kedokteran. Dengan begitu, dokter dan pasien didudukkan dalam kesederajatan sama sebagai pendukung hak dan kewajiban. Dokter dan pasien adalah sama dihadapan hukum dalam kapasitas sebagai subjek hukum.

Dari titik pandang inilah, maka gagasan untuk menempatkan kedudukan informed consent sebagai hal penting terhadap perlindungan hak-hak pasien dalam melakukan tindakan medis, dipandang sangat urgen sebab ini menyangkut tubuh setiap orang. 
Harus juga dipahami bahwa pemaknaan Informed Consent dalam perspektif perlindungan hak pasien, adalah untuk mencegah terjadinya malpraktik dalam tindakan medis yang dilakukan oleh dokter. Artinya, dokter mestinya bertindak sesuai dengan prosedur yang benar, sesuai dengan ketentuan standar operasional yang ditentukan oleh medis.

Pada konteks pemaknaan yang lebih luas, informed consent secara fundamental mendudukkan pasien sama dengan subjek hukum lain di tengah masyarakat, agar kepentingan-kepentingannya terlindungi dari bahaya yang mengancamnya di bidang kesehatan dan butuh pengakuan perlindungan hak dari negara seperti pada masyarakat lainnya. Di sinilah peran negara seharusnya bisa menjamin setiap kepentingan yang menyangkut hak atas kesehatan. Untuk itu, sangat diperlukan sinergitas kerjasama antar lembaga terkait bidang kesehatan, masyarakat dan negara guna memenuhi kepentingan setiap warga negara dalam hal jaminan kesehatan, juga sekaligus merupakan wujud dalam kehidupan berbangsa dan bernegara. Pasien sebagai bagian dari masyarakat lahir sebagai salah satu proses kehidupan bersama melalui interaksi pola tingkah laku yang maknanya dimengerti dan pahami oleh sesama masyarakat yang lain.

Dengan demikian, persetujuan informed consent dapat dimaknai sebagai pengakuan terhadap asas kesamaan antara pasien dan dokter. Pengakuan kesederajatan antara dokter dan pasien tersebut, tidak saja melulu pada batas hubungan hukum bersifat privat (individual), tetapi juga menjangkau pada konteks lebih luas yang menegaskan peran serta negara agar dapat melaksanakan program-program dalam rangka menciptakan derajat kesehatan lebih baik. Sehingga informed consent tidak saja meletakkan tanggungjawab profesionalitas dokter secara individual tetapi juga berkelindan dengan konsistensi tanggung jawab negara sesuai amanah konstitusi yaitu mengupayakan perlindungan persamaan di bidang kesehatan yang merupakan hak bagi setiap warga negara Indonesia. ${ }^{12}$

\section{Urgensi Informed Concent terhadap Per-} lindungan Hak-hak Pasien dalam Konteks Pertanggungjawaban Dokter

Keberadaan informed consent dalam konteks pertanggungjawaban hukum, juga sangat penting, adalah untuk meletakkan batas-batas pertanggungjawaban seorang dokter terhadap tindakan medis yang dilakukan. Menurut penulis, informed consent sekaligus akan menjadi batas demarkasi pertanggungjawaban seorang dokter terhadap tindakan medis yang dilakukannya. Dalam banyak kasus malpraktik kedokteran, polemik antara ikatan dokter dengan penegak hukum kerap berlangsung pada seputar batasan pertanggungjawaban dokter. Sebab itu, informed consent sangat urgen sebagai bentuk informasi kepada pasien mengenai semua tinda-

12 Pemikiran-pemikiran yang dimulai dengan pola kesimbangan hubungan hukum antara pasien dan dokter dalam Informed Consent mencerminkan antara hubungan hukum yang saling membutuhkan di antara keduanya. Bertumpu pada pemikiran, bahwa berdasarkan Undang Undang Dasar 1945 merupakan hukum dasar yang menjadi landasan bagi setiap pengaturan hukum, maka setiap asas yang terkandung harus sesuai dengan nilainilai yang ada di dalam Undang- Undang Dasar 1945, termasuk di dalamnya Informed Consent sebagai asas yang mendasari dalam pembentukan Undang-Undang Kesehatan, Undang-Undang Praktik Kedokteran, dan Undang-Undang Tenaga Kesehatan. 
kan medis yang akan dilakukan. Meskipun informasi yang hendak diberikan itu, baik secara eksplisit maupun implisit. Sehingga, letak urgensitas pemberian informasi tersebut, adalah untuk memudahkan pembuktian bila kelak terjadi perselisihan antara dokter dengan pasien ${ }^{13}$.

Artinya, beban pertanggungjawaban dokter melalui keberadaan informed consent, akan dapat dibuktikan lewat pengadilan secara rasional setelah majelis hakim memeriksa beberapa bukti tindakan medis, apakah tindakan medis yang dilakukan telah berlangsung sesuai dengan prinsip-prinsip profesionalitas kedokteran ataukah tidak. Juga melalui informed consent, pihak dokter dapat membuktikan area batas pertanggungjawabannya terhadap tindakan medis yang telah berakibat bahaya bagi jiwa dan fisik pasien, sebab sudah berada pada wilayah di luar kemampuan dokter (force majeur).

Dengan demikian, informed consent dari segi aspek pertanggungjawaban yuridis, tidaklah ditempatkan sekedar formalitas persetujuan antara dokter dengan pasien, tetapi informed consent hakikatnya adalah membentuk hubungan perikatan antara dokter dengan pasien, yang dalam hubungan perikatan tersebut, berimplikasi melekat ketentuan hukum yang berlaku dan ini sangat berhubungan dengan tanggung gugat profesional menyangkut perjanjian perawatan dan perjanjian terapeutik. Karena sangat berkaitan dengan tanggung gugat profesional, maka transparansi komunikasi antara kedua belah pihak (dokter dan pasien), akan terjaga, pihak petugas kesehatan (dokter)

13 World Medical Association. (2011). Vancouver: "Handbook of WMA Policies", hlm. 193-194 harus mendapat informasi keluhan pasien sejujurnya, demikian pula dari pihak pasien harus memperoleh diagnosis dan terapi yang akan dilakukan.

Keberadaan informed consent bila dikaitkan dengan pertanggungjawaban dokter terhadap pasien, dalam konteks perlindungan hak-hak pasien secara lebih luas, adalah bertujuan melindungi pasien dari tindakantindakan medis yang besifat memperdaya (fraud), menekan (force), dan menciptakan ketakutan $(\text { fear })^{14}$. Artinya, kendati dokter berlindung dibalik profesionalitas dokter terhadap tindakan kelalaian medis yang terjadi, tidak berarti serta merta dapat membebaskan dokter dari segala tuntutan hukum. Sebab dokter dihadapan hukum tetap dipandang sebagai subjek hukum, sehingga tatkala ia melakukan kelalaian atau kesalahan, maka kepadanya tidak dapat dilepaskan dari segala tuntutan hukum baik bersifat perdata, pidana, maupun administrasi.

Dari segi hukum perdata, tolok ukur yang digunakan adalah "kesalahan kecil" (culpa levis), sehingga jika terjadi kesalahan kecil dalam tindakan medis yang merugikan pasien, pihak dokter tentu saja sudah dapat dimintakan pertanggungjawabannya secara hukum. Sebab dalam hukum perdata berlaku adagium "barang siapa merugikan orang lain harus memberikan ganti rugi”. Sedangkan dari segi hukum pidana tolok ukur yang dipergunakan adalah "kesalahan berat" (culpa lata). Oleh karena itu, bila kesalahan kecil (ringan) yang timbul pada pelaksanaan tindakan medis, tentu saja belum dapat dipakai sebagai tolok ukur untuk menjatuhkan sanksi pidana. Sehingga, dalam konteks

\footnotetext{
14 Adami Chazawi, Op.Cit. hlm. 5.
} 
pertanggungjawaban dokter ini, yang digunakan adalah tolok ukur hukum perdata.

Pada konteks pertanggungjawaban dokter inilah, maka perlindungan hak-hak pasien dapat terakomodir melalui konsep informed consent. Alasannya, suatu tindakan medis yang dilakukan oleh pelaksana jasa tindakan medis (dokter) tanpa adanya persetujuan dari pihak pengguna jasa tindakan medis (pasien), sedangkan pasien dalam keadaan sadar penuh dan mampu memberikan persetujuan, maka dokter sebagai pelaksana tindakan medis dapat dipersalahkan dan digugat telah melakukan suatu perbuatan melawan hukum (onrechtmatige daad) berdasarkan Pasal 1365 BW. Hal ini karena pasien mempunyai hak atas tubuhnya, sehingga dokter harus menghormatinya.

Adapun terkait aspek hukum pidana, "informed consent" mutlak harus dipenuhi dengan adanya Pasal 351 KUHPidana tentang penganiayaan. Suatu tindakan invasive (misalnya pembedahan, tindakan radiology invasive) yang dilakukan pelaksana jasa tindakan medis tanpa adanya izin dari pihak pasien, maka pelaksana jasa tindakan medis dapat dituntut telah melakukan tindak pidana penganiayaan yaitu telah melakukan pelanggaran terhadap Pasal 351 KUHPidana.

Inti dari informed consent adalah jaminan perlindungan hak-hak pasien untuk mendapatkan pelayanan kesehatan yang lebih baik. Pada saat dokter memberikan informasi (penjelasan) tentang tindakan-tindakan medis yang hendak dilakukan kepada pasien, maka pada saat bersamaan dokter memiliki kewajiban untuk memberitahukan pasien mengenai kondisinya; diagnosis, diagnosis banding, pemeriksaan penunjang, terapi, risiko, alternatif, prognosis dan harapan. Dokter seharusnya tidak mengurangi materi informasi atau memaksa pasien untuk segera memberi keputusan. Informasi yang diberikan disesuaikan dengan kebutuhan pasien (add content to your paragraph here). Ruang lingkup pemberian informasi yang diberikan sangat tergantung pada pengetahuan medis pasien saat itu. Jika memungkinkan, pasien juga diberitahu mengenai tanggung jawab orang lain yang berperan serta dalam pengobatan pasien.

Sehubungan dengan hak-hak pasien, dalam sebuah penelitian di Florida disimpulkan bahwa setiap orang dewasa yang kompeten memiliki hak dasar menentukan tindakan medis atas dirinya termasuk pelaksanaan dan penghentian pengobatan yang bersifat memperpanjang nyawa pasien. Beberapa pengadilan di AS, membolehkan dokter untuk tidak memberitahukan diagnosis pada beberapa keadaan, terutama terkait dengan diagnosis penyakit yang berat, karena itu menyangkut pertimbangan emosional pasien yang kemungkinan sangat berpengaruh terhadap penyembuhan pasien. Hak-hak pasien dalam konteks informed consent juga berkaitan dengan hak atas informasi tentang kecurigaan dokter terhadap penyakit tertentu walaupun hasil pemeriksaan yang telah dilakukan inkonklusif.

\section{PENUTUP}

Pelayanan kesehatan pada hakikatnya merupakan hak dasar bagi setiap warga negara yang dijamin oleh konstitusi. Karena itu, filosofi dari informed concent dalam ini bahwa setiap orang berhak memperoleh hidup yang lebih baik, yang pada hakikatnya 
Tuhan telah memberikan tubuh pada manusia, selayaknya sebagai individu harus dihargai, termasuk dalam menentukan tindakan medis atas tubuh atau badannya, yang dalam hal ini hubungan pasien dan dokter dengan informed concent yang harus menempatkan hak atas kesehatan pasien yang dijamin oleh UUD 1945. Jadi pada hakikatnya, informed consent adalah suatu proses komunikasi antara dokter dan pasien tentang kesepakatan tindakan medis yang akan dilakukan dokter terhadap pasien (ada kegiatan penjelasan rinci oleh dokter), sehingga kesepakatan lisan pun sesungguhnya sudah cukup.

Penandatanganan formulir informed consent secara tertulis hanya merupakan pengukuhan atas apa yang telah disepakati sebelumnya. Tujuan penjelasan yang lengkap adalah agar pasien menentukan sendiri keputusannya sesuai dengan pilihan dia sendiri (informed decision). Oleh karena itu, pasien juga berhak untuk menolak tindakan medis yang dianjurkan. Pasien juga berhak untuk meminta pendapat dokter lain (second opinion), dan dokter yang merawatnya.

Berpijak dari pandangan inilah, maka kedudukan informed consent sangat urgen sebagai bentuk informasi kepada pasien mengenai semua tindakan medis yang akan dilakukan meskipun informasi yang hendak diberikan itu bersifat eksplisit maupun implisit. Letak urgensitas pemberian informasi tersebut, adalah untuk memudahkan pembuktian dalam rangka pertanggunggjawaban dokter bila kelak terjadi perselisihan dengan pasien.

Sebagai rekomendasi, penulis menyarankan untuk segera dilakukan revisi terhadap Undang-Undang Praktik Kedokteran yang memuat asas informed concent yang menjiwai dalam pengaturan praktik kedokteran di Indonesia. Dalam revisi undangundang tersebut, seyogianya memuat sanksi yang tegas dan jelas dalam hubungan dokter dan pasien ketika melakukan tindakan medis yang harus menempatkan informed concent sebagai bagian tak terpisahkan dari tindakan-tindakan medis yang sedang dan akan dilakukan.

\section{BIBLIOGRAFI}

Adami Chazawi. (2007). Malpraktik Kedokteran. Malang: Bayu Media.

B.M. Stanley, D.J. Walters and G.J. Maddern. (1998). "Informed Consent: How Much Information is Enough?" Australian and New Zealand Journal of Surgery. 68(11): 788-791.

Burke Sarah Elizabeth (2008). The DoctorPatient Relationship: An Exploration of Trainee Doctors' Views. (Dissertation). England: School of Education The University of Birmingham.

Chirisdiono Achdiat. (2006). Dinamika Etika dan Hukum Kedokteran dalam Tantangan Zaman”. Jakarta: Buku Kedokteran EGC.

CIOM. (2002). International Ethical Guidelines for Biomedical Research. Involving Human Subject. Geneva: International Handbook.

Daniel, E, et. al, "Informed consent for clinical treatment" in Canadian Medical Association. (http://www.cmaj.ca/content/184/5/533.full) [Diakses 13 Desember 2012].

M. Jusuf Hanafiah dan Amri Amir. (1999). Etika Kedokteran dan Hukum Kedok- 
teran. Jakarta: Penerbit Buku Kedokteran EGC.

Peraturan Menteri Kesehatan Republik Indonesia Nomor 290/Menkes/Per/III/2008 tentang Persetujuan Tindakan Kedokteran.

Peter Mahmud Marzuki. (2005). Penelitian Hukum. Jakarta: Prenada Media Grup. Philipus. M. Hadjon, (2000). Perlindungan
Hukum Bagi Rakyat Indonesia. Yogyakarta: Peradapan.

Purnadi Purbacaraka. (1982). Hak Milik Keadilan dan Kemakmuran Tinjauan Falsafah Hukum. Jakarta: Ghalia Indonesia.

World Medical Association. (2011). "Handbook of WMA Policies". Vancouver: International Health Association. 